\title{
Work-family conflict and cyberloafing: the mediating role of work stress
}

\author{
Aqsa Kusumawati ${ }^{1}$ and Rosaly Franksiska², \\ 1,2Management Department, Economics and Business Faculty, SatyaWacana Christian University, Indonesia
}

\begin{tabular}{ll}
\hline Abstract & This study was conducted to analyze the effect of work-family conflict on work stress. \\
& Furthermore, we also examine the mediating role of work stress on the relatioship between \\
& work-family conflict on cyberloafing. Results of path analysis on 133 respondents form PT. \\
AIC, Semarang, Indonesia shows that work-family conflict positively affects work stress. \\
This research also indicated that work stress did not act as an intervening variable because \\
the respondents had other stress coping mechanism than cyberloafing.
\end{tabular}

Keywords

work-family conflict (wfc); family interfering with work (fiw); work interfering with family (wif); work stress; cyberloafing

\section{INTRODUCTION}

Workers' conditions and behaviors determine the performance of a company. However, keeping employees stable at work is sometimes beyond control; one of the causes is work-family conflict. Work-family conflict is seen as a factor that plays a role in the corporate and business world. Therefore it requires alignment between work and family so that it can run efficiently (Roboth, 2015).

The unconformity creates stress for the employees, and when they get stress, it can lead to psychological and physical shock, then they will try to find coping mechanism. This coping activity can reduce efficiency in the completion of its task and violate certain work rules (Rahmawati, 2010). The existence of the facilities available in the workplace, for instance, the internet and all other technological advances and gadgets can be used to decrease stress. The use of technological advances to surf the web and other things during work is called cyberloafing. Previous research by Choi (2008) examines the relationship between work and family demands and stress found that both work and family have a relationship to stress. Another study from Basu (2017) found that high levels of employee stress lead to laziness and intention to delay work and using cyberloafing as a diversion from work.

According to Hartijasti and Fathonah (2014), cyberloafing is a counterproductive activity by using the internet for personal purposes that interfere with employee productivity, especially if done excessively. The internet becomes the place to eliminate boredom although it only acts as a temporary solution. This pseudo thing highlighted the digital era and can offer positive and negative sides. The Internet will provide many benefits if its uses can be controlled and utilized according to its function properly such as the using oftechnology and energy from the internet to provide a more qualified model and business innovation (Zhou, 2016), using it otherwise can create lower productivity.

Indonesian Internet Service Provider Association (APJII) research (2014) on the profile of internet users in 2014, the most internet user profiles are people who have worked or entrepreneur as much as 55 percent in Indonesia. In such a sophisticated era, the company can demand its employees to become human resources with a qualified IT; it means that employees must be able to operate IT devices and also use the internet for the needs of the company wisely. However, from research conducted by APJII, it was not uncommon for employees to also socialize using the internet with a variety of social networks that are rife and have the impression of the trend, the percentage means that the intensity of access is also fairly high.

Employees can access the internet for different purposes other than doing office work, and sometimes internet temptation puts employees on hold to work or causes laziness in work (Ardilasari and Firmanto, 
2017). This research attempts to find out whether the problems that exist in the family and the work affect work stress. Furthermore this paper also figures out whether work stress have intervening role in the effect of work-family conflict on cyberloafing behavior.

\section{LITERATURE REVIEW AND HYPOTHESES DEVELOPMENT}

\section{Work-family conflict}

According to Byron (2005) and Kossek et al. (2011), work-family conflict or also called work-family Interference is one type of InterRole Conflict that occurs when the demands of work and family roles are contradictory and create a clash, so it is difficult to choose one of the existing roles. Different people will experience different problems about their work and their family. The difficulty felt by an individual in regulating the role can cause some negligence in several things whether at work or with family, then it causes some friction to each role. This unconformity causes conflict because within each role lies a certain obligation in both work and family (Buhali and Margaretha, 2013). Of course, if someone lives in the family, either having a role as a child or as a parent or as a spouse, circumstances will require that person to act according to the role and can create different problems.

When many things do not go according to plan, they will disturb someone personally and environmentally, the coverage of the environment is the family environment as the starting place and the smallest unit in the social structure, as well as the environment that has a greater scope of the environment than the occupied area. Various problems of role conflict in the family coupled with the factor of the number of workloads, low work flexibility (Gulzar and Khalid, 2016). With all the problems that may arise resulting in dissatisfaction with the work being undertaken, the commitment to the organization is diminished, and the frequent absenteeism, discretion in work becomes narrow, and high turnover rates (Tabassum et al., 2017). According to Bruck, Allen et al. (2002), there are several indicators of workfamily conflict, time-based, behavior-based, strain based. It can be in the form of family interfering with work (FIW) and work interfering with family (WIF) (Agustina, 2008; Vercruyssen and Putte, 2013; Roboth, 2015).
Byron (2005) assumes that FIW occurs when family life (non-work variables) interferes with things that deal with work. FIW refers more contextually beyond the personality moderator (Dai and Chen, 2014). The context depends on the problem that is faced in the family because the problem is always beyond the control of the individual. With different circumstances and the weight of an issue and with a variety of highly diverse traits that are part of the individual, problems can arise at any time, and it was challenging to avoid so that conflicts can create strong psychological pressure on the individual (Turner et al., 2014).

With the work-family conflict that happens, it will be very likely as an individual to seek escape to forget things and situations that occur within the family. For people who have worked with an average time of eight hours a day and five days a week, the time is very long. The office can become a place to neglect family problems or to relax and seek other activities which can make them feel eased. In other cases, long working time is also a problem that arises in the family. Family demand family time but the tasks at work also waiting to be resolved, and this conflict will impact on the decline in quality of work.

WIF is also defined by Byron (2005) as the opposite of FIW, that is when work variables interfere with life in the family. Problems generated from work resulted in a lack of an employee to take a role in his family so that many conflicts occur because there are cases or demands and responsibilities to be resolved in the workplace (Okonkwo, 2014). People often say that family is a priority, but when it is attached to a job, sometimes many things that make a person to set aside family. The family, of course, participate in one's life, will not let a member will feel trouble, but even cause many problems when family too dominate the individual (Agustina, 2008) who also serves as employees or employees who carry out the duties of the company.

In small cases such as making decisions directly related to the company, but the family participated in the interference to create a new commotion and debate that triggered role conflict with the family and with work. Families in Indonesia are extended family, consisting of mother, father, child, grandparent, and other family members (Hardyanti et al., 2017). With many family members and some become economically 
dependent, will directly affect one's work. The action of the role in question is to carry out what is deemed to be accurate and will not bring down one party or both parties of the family and work simultaneously. Byron (2005) and Kossek et al. (2011) incorporates family stress and stress jobs into variables from FIW and WIF as indicators, but from earlier studies suggest that family stress \& work stress has a positive relationship to FIW and WIF (Stoeva et al., 2002). So it cannot be an indicator to know FIW and WIF because it is a separate variable.

\section{Work stress}

Stress is a part of everyday human life, which is the physical, mental and emotional response that comes from challenging things. Automatic stress responses arise when a person feels threatened by the circumstances faced by his environment, as a dynamic thing when the individual is exposed to opportunities, requests or resources to himself as well as the physiological reactions occurring from these demands, whether from outside or within the organization (Sengupta and Sengupta, 2017). Certainly, in this case, the organization in question and associated with employees, i.e. the company.

Employees often experience work stress interpreted according to Beehr and Newman (1978) as a situation where factors related to work interact and change workers, who are forced to deviate from normal function from the usual. Margiati (1999) suggested that work stress could create psychological and social pressure, both in work and with the surrounding environment. Rahmawati (2010) stated that work stress is the inability of a person to be positive with his environment in the company or outside work. The imbalance of roles makes a person depressed. Not to mention the work, they have other demands to be met on the part of the company. The previous study found that work stress will create a variety of illnesses and bad symptoms (Lennartsson et al., 2013). Everyone wants to meet all the demands that exist in life, both for families and jobs with all the circumstances, but it is very difficult to do, and often leads to confusion for the individual to complete the precedence. Work stress has an adverse impact on the individual even can lead to depression; stressful employees are likely to experience depression (Gray-Stanley et al., 2010).
Not everyone can face the pressures of various problems in the various living conditions, as employees are only people who have proactive nature that can make the stress as a trigger factor in the growth of his career (Zhao et al., 2016). Stressor faced will be used as a learning material by people who can manage stress and then can conclude and evaluate to be a consideration in doing and responding to something according to the portion problem. The negative side will not emerge from work stress that can aggravate the health conditions of employees if they can overcome it properly. In summary, work stress can mean unbalanced personal and environmental relationships to the employee's capabilities that are detrimental to their health, and stressors that become obstacles can be intrinsic factors of the work at hand, then bring demands and various responsibilities to be completed (Seçkin-çelik and Ays seçoban, 2016).

There are several dimensions of work stress according to Rahmawati (2010), the first one is physiological; experiencing digestive disorders, as well as headaches caused by the workload. Second, psychological; feeling desperate while working, easy to be offended, difficult to concentrate, like to procrastinate, feeling bored with work, feeling anxious at work, less satisfied with work, lack of enthusiasm in work, unhappy following office activities. Third, behavior; not working, difficult to sleep due to work, decreased appetite due to workload, and the desire to stop working.

\section{Cyberloafing}

Various conveniences are offered through features on the internet for business advancement within a company (Brown et al., 2001). It is impossible for a company to do everything in its traditional way since now the business world has become more advanced. Easy access to everything, just in front of computer screen with internet network, users can browse and can connect with across countries. The ease of communicating with a smartphone with instant messaging features allowing one to connect with the intended person faster, via sms (short message service) or other apps.

However, it is unfortunate when the use of the Internet and IT tools that were initially intended to build a business within the company, but abused by employees for other purposes outside the work affairs (Ozler and 
Polat, 2012). It dramatically reduces productivity; the company will bear the cost of cyberloafing behavior carried out by its employees (Hussain et al., 2016). Therefore, according to Sheikh et al. (2015) and Doorn (2011), cyberloafing are activities conducted by employees using the Internet to explore and access nonrelated goals at work. Cyberloafing activities such as watching YouTube and checking Facebook, as a cover for actual activity (Askew et al., 2014), and reinforced by Gökçearslan et al. (2016) statement that easy access to smartphones can cause a person to do cyberloafing. Another opinion from Harttijasti and Fathonah (2015) that in addition to using office computers at work, cyberloafing can also use gadget and smartphone which usage can exceed eight hours per day.

Doorn (2011) reveals several dimensions of cyberloafing that are done during working hours such as visiting and expressing yourself through social networking sites (Facebook \& Twitter, etc.), instant messaging or online messaging, visiting online discussion forums, and sharing information through blogs. Second, information activity, that is visiting general news sites, searching for jobs, visiting sports-related sites, visiting entertainment news and social news sites, visiting investment and banking sites. Third, leisure activities including visiting non-work related sites, downloading unrelated information, visiting adult sites (sexually explicit), visiting video sharing sites (YouTube, etc.). Last, virtual emotional activities such as online shopping, searching and making friends online.

\section{Hypotheses development}

Giving time means we also give our lives, for what time we use, maybe for some people will choose to invest time for the family. However, for those who are already working, sorting out time for family and work becomes a dilemma. Because worker bounded by work responsibilities, that any thoughts that have been sown in work sometimes lead to many problems into the family known as work interfering with family (WIF). The tension that occurred in the family can also trigger the feelings that disturb the individual as an employee, known as family interfering with work (FIW). Within the scope of the working hours, cyberloafing is another convenient option to distract oneself from conflict (Doorn, 2011). Of course, it will cost the company and could create an unfinished task, and it created laziness. However, some studies show that cyberloafing negatively affects the performance. With uninterrupted task, completion means it will not create problems and will not affect the family (Vitak et al., 2011).

Work-family conflict influences the intensity of work stress experienced by employees. Instability occurs when the role of the family is mixed with tasks that must be completed within the scope of work as the personal responsibility of every employee who has worked and trusted by the company to complete its work as efficiently as possible and to achieve the goals of the company. Previous research conducted to test workfamily conflict has always shown consistent results, namely that work-family conflict always leads to work stress (Vercruyssen and Putte, 2013). Both the problems faced early in originating from the family or FIW, as well as those from work-related problems that affect the family or WIF, have the same effect that is as a factor in the individual that leads to decreased arousal and feel the pressure that culminates in work stress.

H1: work family conflict positively affects work stress.

As hypothesized in hypothesis 1, work family conflict is predicted as determinant of work stress. Furthermore, work stress makes employees lazy at work to complete their tasks and responsibilities (Serhat et al., 2017). The Internet provides a new experience in business, namely by providing much information both for individuals and organizations, for those who can use it well, the internet provides a lot of benefits (Ozler and Polat, 2012). Many employees use the internet to distance themselves from a sense of fatigue caused by work. Finding and conducting activities on the internet with all the features offered to achieve personal goals and override the needs and tasks at work. The internet can be an exciting place to get rid of boredom. Doing cyberloafing is fun to forget for a moment the task at hand.

H2: Work stress mediates the effect of work-family conflict on cyberloafing.

\section{METHODS}

This research is a causal research. Respondents in this study are administrative 
employees of PT. AIC who are authorized to use or access the company's computer, where all the computers are connected to the internet network, and are allowed and can also access the smartphone while working. There are about 200 employees who become the population. Then calculated using Slovin formula resulted in the sample as much as 133 respondents. Employees who use computers and connected to the internet and can access the smartphone are the respondents of this study. The technique sampling used is purposive sampling. The first criteria are existing employees of administrative office that has the authority to use and access the computer; The second criteria are employees that can have and can access the smartphone during business hours. The third criteria are employees that have social media and instant online messaging application. Data analysis technique used in this research is Path Analysis.

\section{RESULTS AND DISCUSSION}

In this research 133 respondents work at PT. AIC, with some characteristics such as age, age at most dominant in range of $37<47$ years (37.6 percent). Female employees also dominated the respondents as much as 56.4 percent, and 69.2 percent have worked for more than ten years at PT. AIC, only 12.8 percent of respondents were single employees. $64.4 \%$ respondents have children as their dependent family members. The commonly used social network was WhatsApp at the highest position of 97.7 percent.

Based on the path analysis as shown in figure 1, the result indicated that work-family conflict posittively affects work stress $(\beta=0,613 ; p<0,01)$. This result supports the hypothesis 1 and it is fit with Vercruyssen and Putte (2013) findings revealed that stress is closely related to the two types of work-family conflict; FIW and WIF.

However, the result show that the direct effect of work-family conflict on cyberloafing $(\beta=-0,005 ; p>0,05)$ and the effect of work stress on cyberloafing $(\beta=0,235 ; p>0,05)$ is not significant. Thus, there is no support for hypothesis 2 ; the effect of work-family conflict on cyberloafing is not mediated by work stress. The most plausible explanation oh this finding is related with characteristics of respondents. With the most age classification is between 37 to 46 years as many as 37.6 percents and more than 46 years as many as 34.6 age groups are included into the generation $X$. According to Hartijasti and Fathonah (2014) generation $X$ were more professional in their work want more time to work so that they can take care of family affairs as well as personal affairs, they use technology for convenience and to increase productivity. From the WIF section with the statement "the time I use for working takes my time for the family" which has an average value of 2.63 with so it is known that within the scope of work that has been quite timeconsuming or they could have been running out of time to do things other than work. With the nature of Generation X that totality and professionalism in their work will focus on what they do rather than only wasting time because, in the opinion of Askew et al. (2014), cyberloafing is part of a most commonly used by employees to waste time. This activity, therefore, is very contrary to the behavior of generation $X$ who was wiser in utilizing the time to work optimally to achieve productivity.

Contradictory things between work

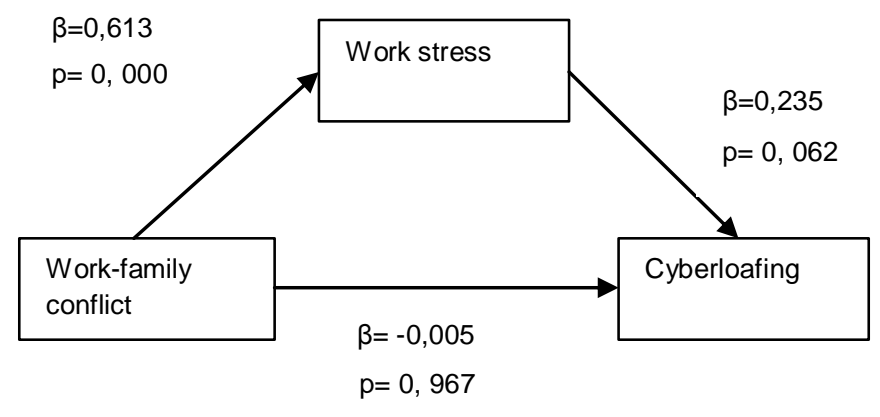

Figure 1.

Result of path analysis 
environment and individual as an employee is called work stress (Beehr and Newman, 1978). The response of this work stress is also very diverse; the prolonged stress affects the emotional, physical, and also behavioral changes (Sengupta and Sengupta, 2017). Associated with cyberloafing stated by Aghaz and Sheikh (2016) that such behavior is one way of recovery from the stress done by individuals. However, this study found that work stress did not influence cyberloafing. The characteristic of age that dominate the respondents were at the age of 37 to 40 and over 40 . This age group had life experiences in dealing with situations, and the age group is classified as having low levels of problems creating a less stressful day (Aldwin et al., 1996). From the attitude and also the more experienced response by adults saying that they are calmer in addressing the problem, with relatively low stress and had no longer necessary to channel it resulting in the score of cyberloafing also categorized as low. This statement was also supported by research from Thayer and Ray (2006) which states that middle and old age groups tend to make fewer online contacts with their counterparts than younger people. The difference of generation at the age raises the gap in the use of technology; young age is more fluent in its development (McMillan and Morrison, 2006).

\section{CONCLUSION}

Our study found that work-family conflict is one of the factors causing work stress. However, our study could not find any support for the notion that work stress mediates the relationship between work family conflict and cyberloafing. The most possible argument is because most of the respondents in this study were categorized as generation $\mathrm{X}$, who more professional in performing their jobs and have another coping mechanism than cyberloafing.

There are some limitation to this research that needs to be addressed for future research. Five employees have not married yet and do not have dependents, which in some case could be considered not having work family conflict.This study does not explain in detail and directly to the respondents that what is meant by cyberloafing is the misuse of the internet that can be accessed using either a personal computer (PC) provided by the office or with a personal gadget or smartphone. This study uses a questionnaire as a tool to collect data, it would be better if future research use observation as method, because cyberloafing will be more described picture-perfect if observed, than only through perception of respondents.

\section{REFERENCES}

Aghaz, A. and a. Sheikh. (2016). Cyberloafing and job burnout: an investigation in the knowledge intensive sector. Computer in Human Behavior, 62: 51-60.

Agustina, Lidya. (2008). Pengaruh work-family conflict terhadap job satisfaction dan turnover intention pada profesi akuntan publik: studi empiris pada kantor akuntan publik di DKI Jakarta dan Bandung. Jurnal IImiah Akuntansi, 7(2), 100-116.

Aldwin, C. M., K. J. Sutton, G. Chaira, A. Spiro III. (1996). Age differences in stress, coping, and appraisal: findings from the normative aging study. Journal of Gerontology: Psychological Sciences, 51B (4), 179-188.

Ardilasari, Noratika, and Ari Firmanto. (2017). Hubungan self control dan perilaku cyberloafing pada pegawai negeri sipil. Jurnal IImiah Psikologi Terapan, 5, 19-39.

APJII.or.id

Askew, Kevin, Buckner John E, Meng U. Taing, Alex llie, Jeremy A. Bauer, and Michael D. Coovert. (2014). Explaining cyberloafing: the role of the theory of planned behavior. Computers in Human Behavior, 36, 510-519.

Basu, Brinda Sampat and Pooja A. (2017). Cyberloafing: the disguised digital way of loafing on the job. IUP Journal Of Organizational Behavior, 6(1), 19-37.

Beehr, Terry A., and John E. Newman.(1978). Work stress, Employee Health, and Organizational Effectiveness: A Facet Analysis, Model, and Literature Review. Personnel Psychology, 31, 665-699.

Brown, Joseph, Nigel Culkin, and Jonathan Fletcher.(2001). Human factors in business-to-business research over the internet. International Journal of Market Research, 43(4), 425-440.

Bruck, Allen, and Spector. (2002). The relation between work-family conflict and job satisfaction: a finer-grained analysis. Journal of Vocational Behavior, 60(3), $336-353$

Buhali, Giovanny Anggasta, and Meily Margaretha.(2013). Pengaruh work-family 
conflict terhadap komitmen organisasi: kepuasan kerja sebagai variable mediasi. Jurnal Manajemen, 13(1), 15-34.

Byron, Kristin. (2005). A meta-analytic of workfamily conflict and its antecedents. Journal of Vocational Behavior, 67, 169198.

Choi, Jaepil. (2008). Work and family demands and life stress among Chinese employees: the mediating effect of workfamily conflict. The International Journal of Human Resource Management, 19(5), 878-895.

Dai, Wanwen, and Xiaoyan Chen.(2014). Consequences of family interference with work: the roles of emotional exhaustion, service sabotage, and negative affectivity. Social, Behavior, and Personality, 42(10), 1613-1628.

Dini.(2013). Pekerja Perempuan Alami Stres Lebih Berat di Kantor. Retreived from https://www.google.com/url?q=http://lifest yle.kompas.com/read/2013/04/02/152401 66/pekerja.perempuan.alami.stres.lebih.b erat.di.kantor\&sa=U\&ved=0ahUKEwjc9r W6u7HWAhVW2GMKHeXwANw4ChAW CBcwBg\&client=internal-udsse\&usg=AFQjCNFP1cXHy5HEswo4HR6 csX_IWUGMDA

Doorn, O.N. van.(2011). Cyberloafing: a multidimensional construct placed in a theoretical framework department industrial engineering and innovation sciences eindhoven university of technology. Retreived from http://www.innovatiefinwerk.nl/sites/innov atiefinwerk.nl/files/field/bijlage/cyberloafin g_a_multidimensional_construct_placed_in_a_theo retical_framework_-

odin_van_doorn_0547224.pdf

Dudovskiy, J. (2016). The ultimate guide to writing a dissertation in business studies: a step by step assistance. Retreived fromResearch-methodology.net

Ghozali, I. (2016). Aplikasi Analisis Multivariate. Semarang: Badan Penerbit Universitas Diponegoro

Gökçearslan, Şahin, Filiz Kuşkaya Mumcu, Tülin Haşlaman, and Yasemin Demiraslan Çevik. (2016). Modelling smartphone addictions: the role of smartphone usage, self-efficacy and cyberloafing in university students. Computers in Human Behavior, 63, 639-649.

Gray-Stanley, J.A., N. Muramatsu, T. Heller, S. Hughes, T.P. Johnson, and J. RamirezValles.(2010). Work stress and depression among direct support professionals: the role of work support and locus of control. Journal of Intellectual Disability Research, 54(8), 749-761.

Gulzar, Mehreen, and Shazia Khalid.(2016). Personality type and work-family conflict in female doctors. Type A Behaviors and Work-family conflict, 66(6), 862-866.

Hardyanti, S., D. Karmiyati, D. S.Hidayati. (2017). Parenting self efficacy ayah pada nuclear dan extended family. Jurnal IImiah Psikologi Terapan, 05(02), 236-249.

Hartijasti, Y. and N. Fathonah.(2015). The Importance of Internet Policies Socialization on Cyberloafing in Indonesian Workplace. Asian Journal of Information and Communications, 7(2), 68-60.

Hartijasti, Yanki, and Nur Fathonah. (2014). Cyberloafing across generation $\mathrm{x}$ and $\mathrm{y}$ in indonesia. Journal of Information Technology Applications \& Management, 21(1), 1-16.

Hussain, Saddam, Farida Saleem, and Muhammad Imran Malik. (2016). Cyberloafing behavior at work. Cyberloafing Behavior at Work, 9 (2), 409-425.

Juanda, Bambang. (2007). Metodologi Penelitian Ekonomi dan Bisnis. Bogor: IPB PRESS.

König, C. J., and M. E. C. d. I. Guardia.(2014). Exploring the positive side of personal internet use at work: does it help in managing the border between work and nonwork?.Computers in Human Behavior, $30,355-360$.

Kossek, Ellen Ernst, Shaun Pichler, Todd Bodner, and Leslie B. Hammer.(2011). Workplace social support and work-family conflict: a meta-analysis clarifying the influence of general and work-family-specific supervisor and organizational support. Personel Psychology, 64, 289-313.

Lennartsson, Anna Karin, To“ res Theorell, Alan L. Rockwood, Mark M. Kushnir, and Ingibjo" RG H. Jonsdottir.(2013). Perceived stress at work is associated with lower levels of dhea-S. PLOS ONE, 8(8).

Margiati, Lulus. (1999). Stres kerja: latar belakang penyebab dan alternatif pemecahannya. Masyarakat, Kebudayaan dan Politik, XII(3), 71-80.

McMillan, S. J. and M. Morrison (2006). Coming of age with the internet: a quantitative exploration of how the internet has become an integral part of young people's lives. New Media \& Society, 8(1), 73-95. 
Okonkwo, Ejike. (2014). Flexible work hour and tenure impacts on time-based work interference with family. Life Psychology, 22(1), 232-238.

Ozler, Derya Ergun, and Gulcin Polat. (2012). Cyberloafing phenomenon in organizations: determinants and impacts. International Journal of eBusiness and eGovernment Studies, 4(2), 1-15.

Rahmawati, Siti. (2010). Analisis stres kerja karyawan pada pt bank rakyat indonesia (persero) tbk cabang bogor. Retreived from

http://repository.ipb.ac.id/handle/1234567 $89 / 32584$

Ramadian, G. (2012). Waspada, stres intai 64 persen pekerja di Indonesia. Retrieved from

https://lifestyle.okezone.com/read/2012/0 9/17/198/691019/waspada-stres-intai-64persen-pekerja-di-indonesia.

Roboth, Jane Y. (2015). AnalisisWork family conflict, StresKerja Dan KinerjaWanitaBerperanGandaPadaYayas an Compassion East Indonesia. JurnalRisetBisnisdanManajemen, 3(1), 33-46.

Sawitri, H. S. R. (2012). Role of internet experience in moderating influence of work stressor on cyberloafing.ProcediaSocial and Behavioral Sciences, 57, 320324.

Seçkin-çelik, Tutku, and Ays,eçoban.(2016). The effect of work stress and coping on organizational justice: an empirical investigation of Turkish telecommunications and banking industries. Management, 11(4), 271-287

Sengupta, Nilanjan, and Mousumi Sengupta. (2017). Stress at workplace. International Journal of Latest Engineering and Management Research (IJLEMR), 2(2),22-29.

Serhat, E.R.A.T., Hakan Kitap Çi, and Pinar ÇÖmez. (2017). The effect of organizational loads on work stress, emotional commitment, and turnover intention. International Journal of Organizational Leadership, 6(2), 221-231.
Sheikh, Alireza, Maryamsadat Sharifi Atashgah, and Mahdi Adibzadegan. (2015). The antecedents of cyberloafing: a case study in Iranian copper. Computers in Human Behavior, 51, 171-179.

Stoeva, Albena Z., Randy K. Chiu, and Jeffrey H. Greenhaus.(2002). Negative affectivity, role stress, and work-family conflict. Journal of Vocational Behavior, 60, 1-16.

Tabassum, Hira, Zaeema Farooq, and Iram Fatima. (2017). Work-family conflict, perceived work overload and work exhaustion in employees of banking sector. Pakistan Journal of Commerce and Social Sciences. 11(1), 439-451.

Thayer, S. E. and S. Ray. (2006). Online communication preferences across age, gender, and duration of internet use. Cyberpsychology and Behavior, 9(4), 432-440.

Turner, Nick, M. Sandy Hershcovis, Tara C. Reich, and Peter Totterdell. (2014). Work-family interference, psychological distress, and workplace injuries. Journal of Occupational and Organizational Psychology, 87, 715-732.

Vercruyssen, Anina, and Bart Van de Putte.(2013). Work-family conflict and stress: indications of the distinctiveness of role combination stress for Belgian working mothers. Community, Work \& Family, 16(4), 351-371.

Vitak, Jessica, Julia Crouse, and Robert LaRose.(2011). Personal internet use at work: understanding cyberslacking. Journal Computers in Human Behavior, 27(5), 1751-1759

Zhao, Xin, Mi Zhou, Qian Liu, and Hua Kang.(2016). Proactive personality as a moderator between work stress and employees. Internal Growth. Social, Behavior, and Personality, 44(4), 603618.

Zhou, Kaile, Shanlin Yang, and Zhen Shao. (2016). Energy internet: the business perspective. Applied Energy, 178, 212222. 